\title{
Noongar Identity and Community Media
}

A definition of successful community media in Australia will undoubtedly point to an example of the growing number of Indigenous media projects that are valued by their respective communities for their ability to support language and culture. Indigenous people all over Australia have successfully demonstrated, with the establishment of community media projects, their desire to challenge the hegemonic and pervasive colonial culture represented by mass media. Mainstream media, with its commercial imperatives and east-coast centred production are incapable of representing the many and diverse Aboriginal cultures that fight to survive, and hopefully thrive, around Australia.

However while Aboriginal media programs in the north of the state, such as Goolarri Media in Broome, have experienced significant success, Perth has struggled to find a media voice for its Noongar people. The Noongar people are the traditional owners of the land situated in the south west of Western Australia. Noongar country stretches from Perth, south east to the coastal town of Esperance and north-west again to Geraldton and is home to fourteen different Noongar tribes or language groups. Noongar country has the largest population of Aboriginal people in the state with 30,000 Aboriginal inhabitants. (Dept. Indigenous Affairs, 2009) In the 2006 Australian Bureau of Statistics census 21,324 people living in the Perth metropolitan area claimed Indigenous heritage. (2006) For such a relatively large Indigenous population it could be expected this community would be home to at least one successful Indigenous community media initiative but, until recently, this has not been the case.

My ongoing involvement and interest in Perth Community television alerted me to the absence of Aboriginal people in local media and prompted a number of questions relating to that absence. This became the focus of my PhD project which draws upon a growing number of literary sources on Indigenous media, as well as my own primary research. What became evident from the outset of the research was that Aboriginal people in Perth, like Aborigines living in other urban centres, are wrestling with issues of identity - both as a community and as individuals. To exacerbate this problem there is an attitude within the nonindigenous community that urban living Aborigines are not 'real' Aborigines, that 'real' Aborigines live in the north-west, and the Noongars in the south have lost their culture. (Host et al., 2009)

This article explores contemporary culture in the Perth Aboriginal community, issues of identity, and how community media is helping to create a sense of identity for an urban Aboriginal community. The story of Aboriginal media in Perth is told here in parallel with the history of the Noongar community and their fight for recognition of a unique contemporary Noongar culture. Past failed community media initiatives are discussed in terms of the valuable lessons they have provided for the newly established Noongar Media Enterprises and 
100.9FM Noongar Radio. The new radio station provides an example by which to postulate the concept of a third space in which contemporary Aboriginal culture comes together with the wider non-indigenous community. The focus here is on radio production; however the term 'media' has been broadly applied to include television and independent film and video production.

As a starting point to finding answers to questions about the absence of Aboriginal community media in Perth I first needed to better understand the Perth Noongar community and their culture. Wherever possible I have sought out Aboriginal voices to speak on the subject of Indigenous media. Interviews were recorded with members of the Perth Aboriginal community who have either been involved with Noongar media or who have significant knowledge of Noongar culture.

The words Aboriginal, Indigenous and Noongar are used in specific contexts throughout this article. Indigenous is generally used in a national context and includes all Aboriginal cultures including Torres Strait Islanders. The word Aboriginal is used when a number of different cultures or language groups are discussed, while Noongar refers specifically to the tribal groups that are the traditional owners of the south-west of Western Australia.

Literary sources that are of particular significance include Lois Tilbrook's book Nyungar Tradition (1983) which is a collection of stories from Aboriginal people from all over the south-west, and Anna Haebich's Broken Circles. (2000) Being Black (Keen, 1994) is a collection of essays from across 'settled' Australia that explores issues of Aboriginal identity and which are also relevant to the Noongar experience. It's still in my heart. This is my country is an account of Noongar history that focuses on the Swan River and Perth communities and seeks to debunk myths about the disappearance of Noongar culture.(Host et al., 2009) Finally, the book $A$ dialogue on Indigenous Identity: Warts ' $n$ ' All by Darlene Oxenham et al. (1999) was to provide significant insight for me, as a Wadjella (non-Indigenous person). This book was written by a group of Aboriginal academics from Curtin University's Centre for Aboriginal Studies and is a transcription of an honest and personal discussion about Aboriginal identity.

\section{Noongar History \& Culture}

One of the first encounters of Europeans for Noongar people was in 1829 with the settlement of the Swan River Colony which is now the location of the cities of Fremantle and Perth. Prior to colonization the south-west region was home to a number of different Aboriginal tribes who had a common language called Noongar (or Nyungar, Nyungah, Nyoongah). The tribe that traditionally occupy the land on which Perth is now located is called Whadjuk (Whadjug).

With colonisation came interaction between Aborigines and white settlers which, by the 1890s, had produced a rising number of mixed descent children. With a 
white Australia sentiment dominating the national consciousness, this was something the state government came to see as a problem especially in regard to the application of laws relating to Aborigines. The question of how to define Aboriginality was eventually answered with a purely biological definition of identity that would change the lives of Aboriginal people forever. The government definition of Aboriginality was embedded in the discriminatory 1905 Aborigines Act and was applicable to any person who was considered to be more than one-quarter Aboriginal descent. The Act effectively gave the government complete control over all Aboriginal people including Aboriginal 'access to land, water, employment, education, and the use of guns and dogs.' (Delmege, 2005: 3)

By practicing an unofficial apartheid the government sought to assimilate Aboriginal people into white society by actively prohibiting the practice of language and culture and removing mixed-descent children from their families. Children were removed from communities all over Western Australia and generally relocated at either the Moore River Settlement just north of Perth or the Carollup Mission south of Perth. To avoid the controlling influence of the 1905 Aborigines Act, people often denied their Aboriginality if their appearance allowed them to do so. This discriminatory act of parliament created far-reaching damage and consequences for Aboriginal people including the erosion of community and cultural identity. It was not until the Native Welfare Act of 1963 that the trends of the previous decades started to be reversed and basic rights were restored to Aboriginal people. (Tilbrook, 1983: 4-5) Aboriginal people were granted citizenship rights in a 1967 federal referendum which saw the demise of the mission and reserve system.

\section{Identity}

Without the accommodation provided by government facilities such as the Moore River Settlement Aboriginal people drifted into the Perth area in search of employment and access to welfare. Aboriginal people, whose roots lay in communities as far away as the Kimberley, as well as Noongars from all over the south-west, now migrated into Whadjuk country. People who for years had been forced to deny their Aboriginality, had been forbidden to speak their language, and forbidden to practice their culture were now required to prove their Aboriginality in order to have access to an increasing number of Indigenous support and welfare schemes. Aboriginal corporate bodies emerged that allowed self-representation and management of Aboriginal affairs, and so the question of how to define Aboriginality again became problematic for both Indigenous and non-Indigenous people.

In discussing who and what is Aboriginal, Queensland academic Marcia Langton says: 
For Aboriginal people, resolving who is Aboriginal and who is not is an uneasy issue, located somewhere between the individual and the state. They find white perceptions of Aboriginality are disturbing because of the history of forced removal of children, denial of civil rights and dispossession of land. (1993: 28)

She notes that legal scholar, John McCorquodale, has found 67 definitions of Aboriginal people, but the Federal Government has, over time, arrived at this definition. 'An Aboriginal or Torres Strait Islander person is someone who:

- Is of Aboriginal or Torres Strait Islander descent.

- Identifies himself or herself as an Aboriginal person or Torres Strait Islander.

- Is accepted as such by the Indigenous community in which he or she lives.

(European Network for Indigenous Australian Rights, 2009)

Yet Aboriginal identity remains problematic because definitions have been constructed by the dominant discourse - by governments, anthropologists and historians rather than by Aboriginal people themselves. Added to the general issues of defining Aboriginality is a perception by the non-Indigenous community that urban dwelling people are not real Aborigines. This view was expressed to me in several personal interviews and the following is an example:

They think that because we live in the city and we stay in a house especially for Noongar people - they say Noongar people have got no culture. Well we do have a culture - we don't have a law - but we do have a culture. (Interview, Perth, 2008)

Associate Professor Ted Wilkes is a Professorial Fellow in Aboriginal health at Curtin University's drug research institute. He explains that in years past white fathers in particular turned their backs on their Aboriginal children and so it was Noongar women who continued to raise their children in a Noongar world.

White people who live in Perth don't believe that Aboriginal people living south of the $26^{\text {th }}$ parallel are genuine and real Aboriginal people. They say, "they're not real black fellas."...We are Noongar. We are the genuine Noongars. We are the modern contemporary Noongar people. And for any white fella to say that we're not is a misnomer. It's an absolute lie. It's a mistruth. (Interview, Perth, 2007)

This challenge to the cultural integrity of urban Aborigines is evidenced by the state government's legal action over the Noongar native title claim to the land on which Perth is located. The Noongar people celebrated on 8 July, 2003 when a Native Title Memorandum of Understanding was signed by government and Aboriginal community members. Soon after, in September of that year, members 
of the South West Aboriginal Land and Sea Council marched with members of 218 Indigenous family groups who represented the entire Noongar nation.

Together, they lodged a single Native Title claim in the Perth Federal Court:

The Single Noongar Claim is having a great healing effect amongst Noongar people, and is enhancing the relationship with the wider community. The Single Noongar Claim is rebuilding the Noongar Nation. (South West Aboriginal Land and Sea Council, 2003)

For the Noongar people of Perth the optimism symbolized by the Single Noongar Claim was short lived. The land claimed within the Perth metropolitan area was heard as a separate proceeding in September 2006. In an interim decision, the judge granted Noongar People native title over the whole of Perth, the first time traditional ownership had been recognized for a capital city. However in April 2008, the State government successfully appealed the decision with the court ruling that the Noongar people had failed to demonstrate the 'continuous practice of their traditional laws and customs by a single society from white settlement to recent times'. (Office of Native Title, 2008; Banks, 2008: 4) In challenging the Perth land claim the government also challenged Noongar cultural integrity which in turn raises questions about how to define Noongar culture.

Culture it is a creative response to the conditions of existence experienced by a group. Through colonisation, racist government policy and the eventual establishment of a political voice, the Noongar community of Perth has evolved and now represents a unique contemporary culture. The same can be said of any contemporary culture and it is unrealistic to expect 'Aboriginal peoples to conform to an externally imposed stereotype of 'the traditional'. (Host et al., 2009: 30-31) How then to describe contemporary Noongar culture and the urban community who live it? For the Perth Aboriginal representatives and community spokespeople who were interviewed, this was a difficult question to answer and words such as 'diverse' and 'complex' were often used.

\section{The Third Space}

Kim Collard is a respected Perth Noongar community leader who provides cultural training and awareness for the wider community. He speaks of a third space that is created when two cultures physically come together as is the case when non-Indigenous people participate in Aboriginal cultural activities such as those that take place in NAIDOC week. Collard's concept of a third space is influenced by Homi Bhabha's concept of hybridity and the third space but is not the same. (Bhabha's colonial context of hybridity 'is not a third term that resolves the tension between two cultures.' (Bhabha, 175))

Kim commissioned a painting by Aboriginal artist Dale Tilbrook entitled 'Coming Together' and it visualises the creation of a third space which is the foundation for all his cultural workshops and consultancy work. (see figure 1) The painting shows two rivers, one followed by black footsteps and the other by white. 


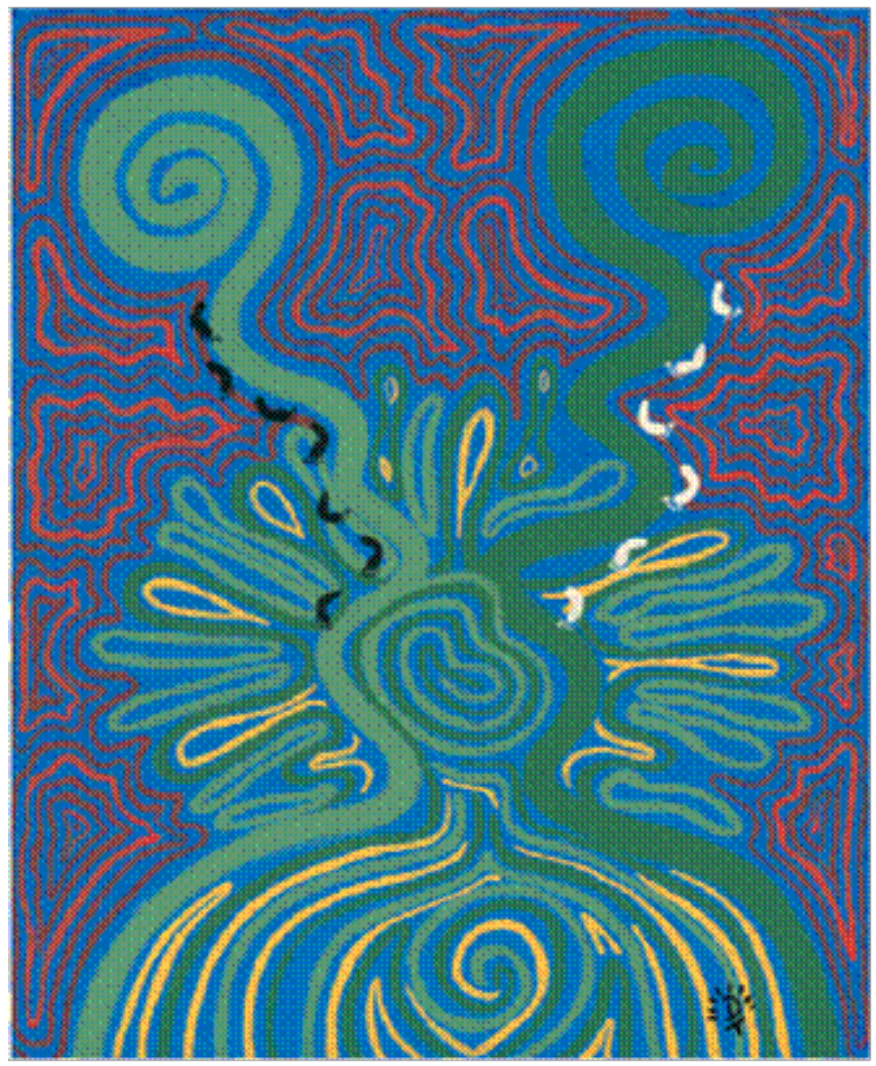

(figure 1)

I quite often use the 'ganmar' metaphor which is the saltwater river meeting the freshwater river. Where those two rivers meet there is a whirlpool. And in that third space there is a lot of turmoil. It's like being inside a washing machine or a whirlpool. So that's that contested site stuff. But if we sit, and we listen, and we talk, that place of turmoil starts to settle down. So the silt settles to the bottom and the freshwater rises to the top ... My language we say 'dat nyen kudditj, wangkiny yah' which means sit and listen and let's talk. (Interview, Perth, 2010)

Noongar identity and contemporary Noongar culture is created inside Kim Collard's concept of a third space and the culturally diverse community of Perth. Contemporary Aboriginal music provides a clear example of contemporary third space culture. Bruce Devenish has been the CEO of an Indigenous music school called 'AbMusic' for seven years and he recognises that there is an expectation from the non-indigenous community that Aboriginal music will have traditional elements such as didgeridoo or tap sticks and that audiences may not recognise the music as 'Aboriginal' without these traditional elements.

Aboriginal musicians advocate that their music, though it may sound like reggae or hip-hop, is Aboriginal music because they are Aboriginal. Bruce Devenish agrees with this definition of Indigenous music: 
'If you write what is true for you then what you write is Aboriginal music because you will be expressing your unique culture and your unique place in that culture.'(Johnston, 2009: 2'15")

Many of Abmusic's musicians can now be heard on Noongar Radio 100.9FM which commenced broadcasting in July 2009. The station was setup with the primary objective of supporting Noongar culture and community in Perth.

Listeners who tune into Noongar radio will hear traditional Noongar language, and styles of music that exhibit diverse elements of Aboriginal culture that range from the traditional sounds of indigenous musicians like Yothu Yindi, the contemporary rock sound of the Aboriginal Yabu Band, and songs with contemporary Aboriginal themes such as the stolen generation from artists like Gina Williams.

\section{Media}

Media can play an important role in supporting this unique Noongar culture as well as assisting in the rediscovery of both individual and community identity. It is demonstrative of the physical third space that Collard promotes. Community media in particular can give a voice to Noongar people in an urban environment that, in the past, has failed to acknowledge a contemporary Noongar culture.

Authors such as Kevin Howley (2005), Linda Fuller (2007)and Ellie Rennie (2006) have provided an international perspective on community and alternative media that supports the importance of these players in the media landscape. This is a sentiment shared by a growing global movement of media activists and community focused supporters. That community television provides a valuable alternative to the culturally homogenous diet offered by mainstream television, and that community media in general is an important contributor to a democratic and inclusive public sphere has been argued and demonstrated by academics from all over the world. Michael Meadows (2001; Meadows and Molnar, 2001; Forde et al., 2009) and Eric Michaels (1986) have published work specifically on the value of Indigenous community media. It is not possible to restate all the arguments in the space of this article and so the following discussion of Noongar community media is premised on the assumption that community media is highly valued for its capacity to effectively support individual communities and cultures. Also of significance is Marcia Langton's book Well, I heard it on the radio and I saw it on the television. (1993) Though written over a decade ago, Langton provides valuable insight into urban Aboriginal communities and Aboriginal media.

The majority of Indigenous media services can be found in remote and rural Australia. In June 2006 there were 160 Remote Indigenous Broadcasting Services (RIBS) - 80 radio and 80 television. (Meadows et al., 2007: 50) The Central Australia Aboriginal Media Association (CAAMA), Warlpiri Media, Goolarri Media and the National Indigenous Radio Network are all examples of 
some of the most successful Indigenous media projects that are operating around the country. However, the type of media generally found in Aboriginal communities in urban Australia is different when compared with those communities in remote and rural Australia where community media initiatives are more common. Marcia Langton explains these differences:

...the policies of control, including 'protection' and 'assimilation', were administered over a prolonged period, more intensively and with more destructive results in settled Australia. One of the effects of these policies, and one of the intentions, was the targeting of the aboriginal individual. In settled Australia, social engineering thinking, which underpinned the "assimilation" policy, sought to shape a new sanitised Aborigine according to certain Anglo-Australian cultural and political dictates. In contrast, the notion of community arose out of the administration of Aboriginal people in remote and rural areas... The aim is to survive as distinctive social and cultural entities. Productions authored by individuals whether in film, video or art, are to some extent typical of Aboriginal people in settled Australia. (1993: 12-13)

Perth is evidence of the differences in media production discussed by Langton. There has been recent generous support for independent Indigenous filmmakers in Perth and results are evident in the three series of "Deadly Yarns" short films that have been broadcast on ABC's Message Stick program. Funded by Screenwest, $A B C$ and Fremantle's Film and Television Institute (FTI) the project has produced short films by at least twenty different Indigenous filmmakers in the past five years. FTI also provides scholarships to Indigenous filmmakers each year, and Murdoch University has the Kulbardi Aboriginal Centre that houses a film and video production centre responsible for the creation of over a dozen Indigenous dramas and documentaries. (2009) However, evidence of successful community media is more difficult to find.

\section{WAAMA}

WAAMA was originally formed as the WA Aboriginal Radio Association (WAARA) in1985. With the launch of AUSSAT the founding members of WAARA saw the possibilities for producing radio programming that could be made available to communities all over the state. Here were similar opportunities as those being taken up by regional broadcasters such as CAAMA in central Australia. WAAMA was formed in September 1986 with plans to expand their activities to include all forms of media, especially television, and to provide professional media training opportunities for Aboriginal people. WAAMA saw itself as becoming a focus, a kind of media hub, for Aboriginal media in the state of WA. They proposed access and training for rural and remote communities wishing to establish their own media programs. With a successful funding application the Australian Broadcasting Association (ABA) granted WAAMA a community broadcasting licence in January 1993. 
With the call sign 6AR, the early years of WAAMA's operation demonstrated a determination to deliver their vision of a professional media service for the Aboriginal community. In 1998 WAAMA was one of nine equal partners in the Channel 31 Community Educational Television Limited Consortium who had been granted a temporary licence to broadcast a community television service in the Perth area. The consortium were successful in the establishment of Access 31 who broadcasted from 1999 to 2008, yet in spite of their initial involvement the Aboriginal community never participated in the management of the station or the production of programs.

By 2001 WAAMA were under investigation by ATSIC after receiving complaints from the Perth Aboriginal community about the service. In 2003 the ABA commenced investigations into the WAAMA radio service that eventually culminated in the revocation of their licence in October 2006. Their failure to recognize and meet the needs of the Community they were licensed to serve is the main reason cited by the Australian Communications and Media Authority (ACMA) and is a problem not uncommon to other community broadcasters. In deed, Perth's youth community broadcaster Groove FM had their licence revoked for the same reasons in 2008. However, the ACMA report does not reveal the immense disappointment and, in many cases, the anger felt by Aboriginal people in regard to the station's closure.

When interviewed people involved with WAAMA cautiously revealed that a power struggle within the organisation had seen the radio station fall into the hands of one family group and it was also operating under non-Indigenous management. WAAMA and 6AR, under this type of management, had lost sight of their original goals and objectives. Self serving interests took precedence over the interests of the Perth Aboriginal community. Much of the disappointment expressed by Aboriginal people relates to the notion of community media as advocacy media. Rather than providing an opportunity for the Perth Aboriginal community to have a political voice and an opportunity to speak out on the serious social issues that confront them daily, WAAMA fell victim to commercial interests.

\section{Noongar Media Enterprises}

With WAAMA's demise the Noongar Radio Action Group was formed and worked for three years on the re-establishment of Aboriginal radio in Perth. Noongar Media Enterprises (NME) evolved from here and its name acknowledges the continuance of a more united Noongar community that was first demonstrated with the Single Noongar Claim on Native title in 2003. A 2007 application to ACMA for a community broadcasting licence reflects WAAMA's original objectives but with a significantly different use of language. While WAAMA identified as an Aboriginal media service, Noongar Media Enterprises identifies as a Noongar organisation recognising a unique and vibrant Noongar language and culture, and consequently has a clear and specific objective in the 
representation of the Noongar community. In outlining their objectives Noongar Media Enterprises state that they aim:

...to provide Noongar people with a media that recognizes (sic), respects and affirms our distinct identity and inherent rights and responsibilities in Australia (sic) society as Noongar people. (2007: 3)

The promotion and preservation of a unique Noongar culture is a clear priority in the Noongar Media Enterprises business plan. The reader is reminded of past government policies that have prohibited the practice of culture and contributed to the suffering of the Noongar people. Cultural integrity is also highlighted with reference to the Federal Court's recognition of Noongar culture in the 2006 Noongar native title decision. Language is discussed as an essential part of culture and will be a focus for Noongar media who promote the broadcast of traditional language programs as well as 'Noongar English' programs.

The focus is Noongar people and culture - Noongar identity - and is expressed here by one of NME's enthusiastic members:

I think that Noongar media in particular plays a really important role in cultural maintenance. What we're doing essentially is a modern take on a very ancient and traditional cultural activity. The story telling, the communication and stuff, our culture is a very oral culture and this is really an extension of that. It's fantastic. (Gina Williams, Past Station Manager, Personal Communication: 2009)

Noongar Radio commenced broadcasting in July 2009. The station has a weekly Noongar language program, runs regular healthcare messages created specifically for Aboriginal people, broadcasts the NIRS news service, and has a policy that ensures every third song heard on Noongar Radio is an Indigenous artist. Listeners are reminded constantly of the station's identity with station promos that exclaim "I love Noongar music" and numerous recordings of the voices of community members declaring their enthusiasm for Noongar Radio are replayed at intervals throughout the day. A weekly prisoner request program has recently commenced in recognition of the large numbers of Aboriginal people that occupy Perth's prisons. (personal communication, 2010)

Michelle White is the current Station Manager and explains how the Noongar Radio hosts are told to 'just be themselves'. This translates to a way of speaking that is distinctly Noongar, even though it is not traditional Noongar language. Listeners confirm that they identify with the Aboriginal radio presenters at the station because of this distinct way of speaking -they don't 'sound like a Wadjella'. (Personal communication, 2009)

The station has made a strong connection with the community as was evidenced by the estimated 10,000 people who attended the Too Solid Music Festival 
organized by the station for Australia/Survival Day celebrations. Noongar Radio and the Koori Mail were the only media outlets to promote the event. Jade Masters, the event organizer is quoted as saying '... it gave us a chance to celebrate our cultural heritage with all Australians.' While the culture that was on display at the Too Solid Music Festival included traditional Noongar dancers, the music played was a mix of rock, reggae and hip-hop style music. Masters 'was overjoyed to see so many non-Indigenous Australians supporting the festival.' (Koori Mail, p37) Engagement with the station by non-Indigenous listeners is further evidenced by this comment from a listener:

...love your station and the music. Listen to it all the time. Feel what you bring across is so special to all people.

$\mathrm{p}, \mathrm{s}$ Am not indigeonous. Just a Aussie

A Noongar Radio listener, in a letter to the station, provides evidence of how the radio station contributes to a sense of identity:

I listen to the R\&B show every Friday and I'm so proud that us Noongars in WA finally have something solid to look forward to and listen to and finally the Wadjellas know who we are.

A group of researchers from Griffith University conducted an extensive survey in 2007 of community media audiences. Their findings for Indigenous media revealed that audiences recognised objectives and values that were distinctly different from other community media. The authors provide evidence for Indigenous media as an essential service and quote from an interview with a Palm Island resident who talks about Aboriginal radio:

It gives us identity, a process of identifying ourselves so we get closer to ideas from 40,000 years of culture not just 200 years. (Meadows et al., 2007: 53)

Unlike WAAMA, NME have adopted the community media values and objectives evidenced by this audience survey and typical of the community media projects working in rural and remote Aboriginal communities. However, urban community media projects like Noongar Radio are more likely to involve the non-indigenous community as both participants and listeners and so exhibit to a greater degree the concept of 'coming together' that is Collard's third space.

\section{Conclusion}

In considering the value of community media for the Perth Noongar community it is worth considering the research of three significant writers in the field of Indigenous media. Firstly, Eric Michaels, after researching the Aboriginal use of television in Yuendumu in central Australia, promotes a community media model because it is locally based and best able to support language and culture. (1986: 
xv) Secondly, I refer to Marcia Langton who explains how Aboriginality is 'remade over and over again in a process of dialogue, of imagination, of representation and interpretation. Both Aboriginal and non-Aboriginal people create "Aboriginalities"...' (1993: 33) The Griffith University audience survey supports this idea:

...both Indigenous and non-Indigenous (audiences), described Indigenous media as their main source of information about Indigenous community events. Some suggested Indigenous media was the major element in the reconciliation process. (Meadows et al., 2007: 52)

Lastly, Michael Meadows describes his experience in Yuendumu where he attended a traditional Aboriginal women's ceremony as their children danced to the sounds of Yothu Yindi at a disco just a short distance down the road. 'Two "versions" of culture exist side by side...in an apparently unproblematic relationship.' (Meadows, 1994: 271) The Yuendumu disco is one example of the diverse cultural production that has evolved in response to colonisation. Meadows illustrates the diversity of responses by Indigenous people with further examples of Warlpiri media in Australia and Inuit media in Canada. I would add Noongar Radio and the Too Solid Music Festival to his list and conclude with Meadows' assertion that this is 'about reclaiming identity and the right to participate in identity construction.'(Meadows, 1994: 287)

For the Perth Aboriginal community, still recovering from the loss of community and identity created by racist government policy, Noongar radio is demonstrating its ability to support not only traditional culture and language but also contemporary Noongar culture. Noongar radio represents a complex and diverse community identity. It represents a third space occupied by both the Perth Aboriginal community and the wider non-indigenous community who are invited to participate both as audience and volunteer. In the spirit of Kim Collard's 'ganmar' metaphor, Noongar Radio provides opportunity for the community of Perth, black and white, to 'come together' - 'to sit and listen and talk.'

(4,975 words) 


\section{BIBLIOGRAPHY}

Australian Bureau of Statistics (2006). "2006 Census of Population and Housing." Retrieved 30/3/09, 2009, from http://www.censusdata.abs.gov.au/ABSNavigation/prenav/ViewData?\&acti on $=404 \&$ documentproductno $=5 \&$ documenttype $=$ Details $\&$ tabname $=$ Details \&areacode $=5 \&$ issue $=2006 \&$ producttype $=$ Community\%20Profiles \& \&produ cttype=Community\%20Profiles\&javascript=true\&textversion=false \&navma pdisplayed=true \&breadcrumb=LPD\&\&collection=Census \&period=2006\&pr oducttype $=$ Community\%20Profiles\&\#Indigenous\%20Profile.

Noongar Nation Media Association, (2007). Noongar Nation Media Association Business Plan. Perth. 3.

Banks, A. (2008). Appeal puts native title case in limbo. The West Australian. Perth, West Australian Newspapers Ltd: 4.

Bhabha, H. Location of Culture.

Centre, K. A. (2009). "Kulbardi Productions." Retrieved 19/5/2009, 2009, from http://www.kulbardiproductions.com.au/index.php.

South West Aboriginal Land and Sea Council, (2003). "The Single Noongar Claim. A New Way Forward." Fact Sheet Retrieved 7/4/09, 2009, from http://ntru.aiatsis.gov.au/ifamp/decision/pdfs/swalsc02.pdf.

Delmege, S. (2005) "A trans-generational effect of the 1905 Aborigines Act (WA): The making of the fringe-dwellers in the south west of Western Australia." Murdoch University Electronic Journal of Law 6, 3

Department of Indigenous Affairs, (2009). "DIA Region - Metro Wheatbelt."

Retrieved 30/3/09, 2009, from http://www.dia.wa.gov.au/OurBusiness/Around-The-Regions/Region-Metro-Wheatbelt/.

Forde, S., K. Foxwell and M. Meadows (2009). Developing Dialogues. Bristol, Intellect Ltd.

Fuller, L. (2007). Community Media. New York, Palgrave MacMillan. 
Host, J., C. Owen and S. W. A. L. a. S. Council (2009). "It's Still in my Heart, This is My Country." The Single Noongar Claim History. Perth, UWA Publishing.

Host, J., C. Owen and S. W. A. L. a. S. Council (2009). "It's Still in my Heart, This is My Country." The Single Noongar Claim History. Perth, UWA Publishing.

Howley, K. (2005). Community Media. People, Places, and Communication Technologies. Cambridge, Cambridge University Press.

Johnston, M. (2009). Noongar Dandjoo. Series 2. Perth, Curtin University: 2'15".

Keen, I., Ed. (1994). Being Black. Canberra, Aboriginal Studies Press.

Langton, M. (1993). Well, I heard it on the radio and I saw it on the television...". Woolloomooloo, Australian Film Commission93.

Langton, M. (1993). Well, I heard it on the radio and I saw it on the television...". Woolloomooloo, Australian Film Commission93.

Langton, M. (1993). Well, I heard it on the radio and I saw it on the television...". Woolloomooloo, Australian Film Commission93.

Langton, M. (1993). Well, I heard it on the radio and I saw it on the television...". Woolloomooloo, Australian Film Commission93.

Meadows, M. (1994). "Reclaiming a Cultural Identity: Indigenous Media Production in Australia \& Canada." Continuum 8(2): 271.

Meadows, M. (1994). "Reclaiming a Cultural Identity: Indigenous Media Production in Australia \& Canada." Continuum 8(2): 287.

Meadows, M. (2001). Voices in the Wilderness. Images of Aboriginal People in the Australian Media. Westport CT, Greenwood Press.

Meadows, M., S. Forde, J. Ewart and K. Foxwell (2007). Community Media Matters, Griffith University. 50.

Meadows, M., S. Forde, J. Ewart and K. Foxwell (2007). Community Media Matters, Griffith University. 53.

Meadows, M., S. Forde, J. Ewart and K. Foxwell (2007). Community Media Matters, Griffith University. 52. 
Meadows, M. and H. Molnar (2001). Songlines to Satellites: Indigenous Communication in Australia, the South Pacific and Canada. Annandale, Pluto Press Australia.

Michaels, E. (1986). Aboriginal Invention of Television - Central Australia 1982 86, Australian Institute of Aboriginal Studies

Michaels, E. (1986). Aboriginal Invention of Television - Central Australia 1982 86, Australian Institute of Aboriginal Studies

Oxenham, D., J. Cameron, K. Collard, P. Dudgeon, D. Garvey, M. Kickett, T. Kickett, J. Roberts and J. Whiteway (1999). A Dialogue on Indigenous Identity: Warts 'n' All, Gunada Press.

Rennie, E. (2006). Community Media. A Global Introduction. Lanham, Rowman \& Littlefield Publishers Inc.

European Rights, E. N. f. I. A. (2009, 27/03/09). "Who is Indigenous?", from http://www.eniar.org/culture.html.

Tilbrook, L. (1983). Nyungar Tradition. Glimpses of Aborigines of South-Western Australia 1829-1914. Perth, University of Western Australia Press.

Tilbrook, L. (1983). Nyungar Tradition. Glimpses of Aborigines of South-Western Australia 1829-1914. Perth, University of Western Australia Press.

Title, O. o. N. (2008). "Claims:South West." Retrieved 7/4/09, 2009, from http://www.nativetitle.wa.gov.au/claims South West.aspx.

\section{INTERVIEWS}

Dennis Simmons, Interviewed by Author. August 2008. Perth, Western Australia.

Associate Professor Ted Wilkes. Interviewed by Author. 15 February, 2007. Perth, Western Australia

Dennis Eggington. Interviewed by Author. 17 April, 2008. Perth Western Australia.

Gina Williams. Interviewed by Author. 24 February, 2009. Perth Western Australia. 
Michelle White. Interviewed by Author ????, 2010. Perth Western Australia. 